\title{
Anatophysiology of Vouacapoua americana Aubl. in the juvenile phase: A species included in the IUCN red list of threatened species
}

\author{
Anatofisiologia de Vouacapoua americana Aubl. na fase juvenil: uma espécie incluída na lista \\ vermelha de espécies ameaçadas da IUCN \\ Anatofisiología de Vouacapoua americana Aubl. en la fase juvenil: una especie incluida en la lista \\ roja de especies amenazadas de la UICN
}

Solange Henchen Trevisan

ORCID: https://orcid.org/0000-0002-6376-0336 Universidade Federal do Pará, Brazil E-mail: soltrevisan26@yahoo.com.br

Raírys Cravo Herrera

ORCID: https://orcid.org/0000-0002-9699-8359 Universidade Federal do Pará, Brazil E-mail: rairys@gmail.com

Thiago Bernardi Vieira ORCID: https://orcid.org/0000-0003-1762-8294 Universidade Federal do Pará, Brazil E-mail: thiagobernardi007@gmail.com

Maike Vieira Drosdosky

ORCID: https://orcid.org/0000-0002-4615-7500 Universidade Federal do Pará, Brazil E-mail: drosdosky.maike@gmail.com

Roberto Lisboa Cunha

ORCID: https://orcid.org/0000-0002-2964-7938 Universidade Federal do Pará, Brazil E-mail: lobo_da_costa@hotmail.com Alisson Rodrigo Souza Reis ORCID: https://orcid.org/0000-0001-7182-4814 Universidade Federal do Pará, Brazil E-mail: alissonreis@ufpa.br

Lenaldo Muniz de Oliveira

ORCID: https://orcid.org/0000-0002-3411-2225 Universidade Estadual de Feira de Santana, Brazil

E-mail: lenaldo.uefs@gmail.com

\begin{abstract}
The Amazon is undergoing environmental changes that can cause morphological and physiological changes in plants. The general objective of this study was to evaluate the anatomical and eco-physiological features of Vouacapoua americana during development in the Brazilian Amazon. It was observed that the stomata only occur in the abaxial face. Secretory structures are present throughout the leaf blade. In the central vein and petiole region it was observed that the xylem occupies the vein's central part, presenting an arc shape. The eco-physiological evaluations revealed that the dry period presented higher values of leaf temperature and steam pressure deficit, and lower values of leaf humidity, stomatal conductance, and transpiration. Anatomical and physiological differences occur at each stage of development.
\end{abstract}

Keywords: Endangered species; Leaf anatomy; Gas Exchange; Brazilian amazon.

\section{Resumo}

A Amazônia está passando por mudanças ambientais que podem causar alterações morfológicas e fisiológicas nas plantas. O objetivo geral deste estudo foi avaliar as características anatômicas e eco-fisiológicas de Vouacapoua americana durante o desenvolvimento na Amazônia brasileira. Observou-se que os estômatos ocorrem apenas na face abaxial. Estruturas secretoras estão presentes em toda a lâmina foliar. Na nervura central e região do pecíolo observou-se que o xilema ocupa a parte central da nervura, apresentando forma de arco. As avaliações ecofisiológicas revelaram que o período de seca apresentou maiores valores de temperatura foliar e déficit de pressão de vapor, e menores valores de umidade foliar, condutância estomática e transpiração. Diferenças anatômicas e fisiológicas ocorrem em cada estágio de desenvolvimento. 
Palavras-chave: Espécies ameaçadas de extinção; Anatomia foliar; Trocas gasosas; Amazônia brasileira.

\section{Resumen}

La Amazonía está experimentando cambios ambientales que pueden provocar cambios morfológicos y fisiológicos en las plantas. El objetivo general de este estudio fue evaluar las características anatómicas y ecofisiológicas de Vouacapoua americana durante el desarrollo en la Amazonía brasileña. Se observó que los estomas solo ocurren en la cara abaxial. Las estructuras secretoras están presentes en toda la lámina de la hoja. En la región de la vena central y pecíolo se observó que el xilema ocupa la parte central de la vena presentando forma de arco. Las evaluaciones ecofisiológicas revelaron que el período seco presentó mayores valores de temperatura foliar y déficit de presión de vapor, y menores valores de humedad foliar, conductancia estomática y transpiración. Las diferencias anatómicas y fisiológicas ocurren en cada etapa del desarrollo.

Palabras clave: Especies en peligro de extinción; Anatomía foliar; Intercambio de gases; Amazonia brasileña.

\section{Introduction}

Global climate change, which is mainly responsible for the increase in temperature and decrease in precipitation within the Amazon (Hoffmann at al., 2018), has led to a series of morphological, physiological, biochemical, and molecular changes in plants, negatively affecting their growth and productivity (Wang et al., 2001). Plants can be directly or indirectly affected by temperature change, directly via photosynthesis and respiration, and indirectly by an alteration in the stomata functioning (Berry \& Bjorkman, 1980). Plants may also have high mortality rates from climate change (Allen et al. al., 2010).

Light is one of the most important resources to the structure and operation of the vegetal community (Jardim, Silva, Melo Júnior, 2018), as is water. Well above average rainfall in some regions of the country, evident droughts in others, extremely hot summers, torrential rain and hurricanes that destroy thousands of houses, are events that come up becoming more and more frequent. In Brazil, until a few years ago, the occurrence of of such extreme weather events. However these extreme weather events are not a particularity of Brazil, being registered worldwide; the changes caused global warming, including tropical ecosystems by reducing the levels of precipitation and evapotranspiration (Marques et al., 2011).

Among the native Amazonian species, environmental factors are affecting the anatophysiology of acapu (Vouacapoua americana Aubl. - Fabaceae - Caesalpinoideae), further compromising its categorization as a species threatened with extinction (MMA, 2014), based on the list provided by the International Union for the Conservation of Nature (IUCN). There is a demand for recovery strategies for the fragmented population and the characterization of its eco-physiological responses.

Additionally, no reports are available concerning the leaf anatomy of the genus Vouacapoua. Knowledge of the anatomical characteristics of leaves is important because it provides subsidies for plant group classifications and their variations in relation to environmental and ecological conditions (Tomlinson, 1990; Passos \& Mendonça, 2006).

The analysis of leaf anatomy and stomatal conductance is successfully used to investigate water stress in cultivated plants (Batista et al., 2010) and may be promising as a parameter for wild forest species. Stomatal activity acts as an indicator of the ambient water conditions and, in the case of stomatal conductance, it is proportional to the stomatal opening diameter, which depends upon environmental factors (Rodrigues et al., 2011). Measuring these traits in a biodiverse region under exceptional drought conditions contributes to our understanding of plant drought responses (Pivavorroff, Cook, Santiago, 2018).

Given these facts, it is important to understand the anatophysiology of Acapu in the juvenile phase under the natural conditions of the Amazon climate, aiming at contributing information towards the conservation of the species in the face of possible scenarios of climate change. The present study aimed at describing the leaf anatomy and stomatal behavior of $\mathrm{V}$. americana during development in the Amazon forest understory. 


\section{Methodology}

The survey was conducted in a fragment of primary forest on "terra firme" (dry land), at the geographic coordinates $03^{\circ} 30^{\prime} 46.3^{\prime \prime}$ south latitude and 52 $47^{\prime} 26.5^{\prime \prime}$ west longitude, located in the municipality of Medicilândia, Pará, Brazil. Here, there is a rainy season between January and June and a dry season between July and December (Cristopherson, 2012). Soil samples were collected for their characterization.

During the rainy season, for anatomical evaluations, $15 \mathrm{~V}$. americana individuals were analyzed in two developmental categories, being classified according to Silva et al. (2005), into: seedling (height $\geq 30 \mathrm{~cm}$ and diameter $<2.5 \mathrm{~cm})$ and stick $(2.5$ $\mathrm{cm} \leq$ diameter $<5 \mathrm{~cm})$.

Mature and fully expanded leaflets were chosen and stored in F.A.A.70. Subsequently, the samples were dehydrated in a butyl series and included in histological paraffin (Johansen, 1940). The determination of stomatal density was performed by staining the samples with safranin and astra blue and then counting the stomata under an optical microscope. Then, the projection was made on graph paper on top of slides to determine the area considered. Measurements of the thickness of the vein, blade, adaxial and abaxial cuticle, adaxial and abaxial epidermis, and parenchyma were determined with the aid of a micrometer eyepiece.

The leaf blade was divided into the apex, median, and base. For each of these regions, sections were obtained from the central vein, intermediate portion, and edge. Transverse sectioning (7-15 $\mu \mathrm{m}$ thick) was performed on a semi-automatic rotary microtome (Leica RM 2245). The permanent slides were assembled in synthetic resin and the semi-permanent slides in aqueous glycerin (Kaiser, 1880). The photomicrographs were obtained using a Motic microscope with a 5.0 pixel coupled digital camera, paired with the Opticam 2.0 software.

For a comparison of the anatomical data of different V. americana development categories (seedling and stick), the Shapiro-Wilk normality and Levene's variance homogeneity tests were applied. Data concerning thickness of the cuticle on the adaxial and abaxial faces $(\mu \mathrm{m})$ and thickness of the epidermis on the abaxial face $(\mu \mathrm{m})$, which presented the same values for all individuals, were not analyzed.

Vein thickness $(\mu \mathrm{m})$ and parenchyma $(\mu \mathrm{m})$ data were tested for normality and homoscedasticity and found to be parametric. Hence, a one-way ANOVA at the 5\% probability level was used. For the variable's stomatal density (mm-2), blade thickness $(\mu \mathrm{m})$, epidermis on the adaxial face $(\mu \mathrm{m})$, palisade parenchyma $(\mu \mathrm{m})$, and spongy mesophyll ( $\mu \mathrm{m})$, the KruskalWallis test at the 5\% significance level was applied. When a significant difference was found, the means were compared using the Tukey's test at the 5\% significance level. To perform these statistical analyses, the Platform $\mathrm{R}$ version 3.1 .2 was used.

The rainfall, global radiation, temperature, and air humidity data for the study site were provided by the National Institute of Meteorology (INMET, 2016). The radiation data were transformed according to the McCree (1981) conversion table for the photosynthetically active radiation unit (PAR in $\mu \mathrm{mol} \mathrm{m-2} \mathrm{s-1).}$

The physiological analyses were performed in at least five individuals in five evaluations/leaves/days, and the evaluation times were from $6: 30$ to $7: 30,8: 30$ to $09: 30,11: 30$ to $12: 30,14: 30$ to $15: 30$, and 16:30 to 17:30.

The variables analyzed were: chlorophyll $(\mathrm{Cl})$, using a portable chlorophyll meter (AtLeaf®); stomatal conductance (Gs); leaf temperature (Tleaf); leaf humidity (Uleaf), using a portable SC-1/Decagon® porometer; deficit of vapor pressure (DVP); and transpiration (T) deficit. The DVP and transpiration values were calculated using the methods proposed by Landsberg (1986) and Buck (1981), respectively.

The photosynthetically active radiation reaching the leaf was measured under natural light at the same time as the physiological evaluations, using the Apogee Quantum sensor model MQ-300 Series.

The chlorophyll, stomatal conductance, leaf humidity, leaf temperature, PAR, DPV, and transpiration, as a function of seasonality, were tested using a repeated-measures analysis of variance (ANOVA) and the Tukey's test at the 5\% significance 
level.

To evaluate which factors influenced the eco-physiological response of V. americana, a Permutational Multivariate Analysis of Variance (PERMANOVA) was performed based on the Euclidean distance similarity matrix. This was done considering two factors: seasonality, Acapu development categories, and time of day. Significant factors and their interactions were analyzed by comparing t-statistics with 999 permutations. To verify the correlation between the eco-physiological variables, a redundancy analysis (RDA) was performed.

\section{Results and Discussion}

According to the soil analysis, the study site is classified as dystrophic yellow latosol, with a pH of 5, high aluminum content $(1.15 / 100 \mathrm{ml})$, and very low fertility $(18.13 \%)$. Precipitation in the municipality of Medicilândia has a mean of 2059.5 $\mathrm{mm}$, but in 2015 registered only $1619 \mathrm{~mm}$, with $1410 \mathrm{~mm}$ corresponding to the rainy season and $209 \mathrm{~mm}$ to the dry season (INMET, 2016). This difference is explained by the fact that in 2015 the El niño climate phenomenon occurred, leaving the Amazon region warmer and drier.

The rainfall during November 2015 (dry period) was $15.2 \mathrm{~mm}$ and the mean temperature was $27.7^{\circ} \mathrm{C}$. In contrast, during April 2016 (rainy season) the rainfall was recorded at $96.8 \mathrm{~mm}$ and the mean temperature at $25.6{ }^{\circ} \mathrm{C}$ (INMET, 2016).

For this subfamily, the characteristics of the leaf anatomy include: dorsiventral leaves; predominantly paracytic stomata; mainly hypostomatic leaves; scarce stomata on the adaxial face, although in some cases stomata are widespread on both sides; sporadic occurrence of druses; and frequent secretory structures (Watson, 1981). Tissue in the lower part of the mesophyll resembling a palisade parenchyma was found, but it was not possible to determine whether it was in fact a parenchymal or epidermal tissue called the "parenchyma tending to palisade" employed by Moreira-Coneglian and Oliveira (2006).

The stomatal density of the seedlings, and sticks showed approximate values, as described in Table 1, indicating that all analyzed V. americana individuals have the same gas exchange efficiency, especially with regard to $\mathrm{CO} 2$ absorption (Boeger and Wisniewski, 2003). In addition, according to Fermino Júnior (2004), species with hypostomatic leaves, such as V. americana, can occupy several environments, as this stomatal pattern can minimize the water loss to the atmosphere, allowing this species to occupy environments with higher temperatures and light incidences.

This stomatal density also indicates that the plants did not undergo water stress during the study period, since the number and size reduction of the stomata are signs of adaptation to water deficiency. 
Table 1 - Mean values* of the anatomical variables of V. americana, in the seedling and stick, two stages.

\begin{tabular}{lll}
\hline Variables & Seedling & Stick \\
\hline Stomatal density $\left(\mathrm{n}^{\circ} \mathrm{mm}^{-2}\right)$ & $738.8 \mathrm{a}$ & $712,4 \mathrm{a}$ \\
\hline Vein thickness $(\mu \mathrm{m})$ & $410 \mathrm{a}$ & $516 \mathrm{~b}$ \\
\hline Surface thickness $(\mu \mathrm{m})$ & $95 \mathrm{a}$ & $92 \mathrm{a}$ \\
\hline Adaxial cuticle thickness $(\mu \mathrm{m})$ & $2.5 \mathrm{a}$ & $2.5 \mathrm{a}$ \\
\hline Abaxial cuticle thickness $(\mu \mathrm{m})$ & $7.5 \mathrm{a}$ & $7.5 \mathrm{a}$ \\
\hline Adaxial epidermis thickness $(\mu \mathrm{m})$ & $8.0 \mathrm{a}$ & $8.0 \mathrm{a}$ \\
\hline Abaxial epidermis thickness $(\mu \mathrm{m})$ & $7.5 \mathrm{a}$ & $7.5 \mathrm{a}$ \\
\hline Palisade parenchyma thickness $(\mu \mathrm{m})$ & $26 \mathrm{a}$ & $27.5 \mathrm{a}$ \\
\hline Spongy parenchyma thickness $(\mu \mathrm{m})$ & $27.5 \mathrm{a}$ & $25.0 \mathrm{a}$ \\
\hline Parenchyma thickness tending to palisade $(\mu \mathrm{m})$ & $14.5 \mathrm{a}$ & $11.88 \mathrm{a}$ \\
\hline
\end{tabular}

* Different letters on the same line mean that the mean values of each stage are statistically different $(\mathrm{p}<0.05)$. Sorce: Authors.

A higher vein thickness was observed in the stick, because in the seedlings, although the leaves were already fully expanded, they were still at the beginning of maturity. The thickness of the cuticle and epidermis, on both the adaxial and abaxial faces, did not show statistical differences between the developmental categories (Figore $1 \mathrm{~A}-\mathrm{G}$ ). Cuticle thickening is a response observed in plants subjected to high irradiance conditions, as it decreases transpiration and prevents water loss through the stomata (Gurevitch et al., 2009).

Therefore, the fact that there is no difference between the cuticle and epidermis thickening between seedlings and sticks, may be due to the similar radiation conditions in the understory of the forest and the lower light requirement because it is a late secondary species in ecological succession. 
Figure 1 - Epidermis of V. americana. (A) Frontal view of the adaxial and abaxial faces. (B) Frontal view of the abaxial face. (C) Frontal view of the abaxial face, showing the tetracitic and anomocytic stomata. (D) Cross-section of the leaf edge with the palisade parenchyma, spongy parenchyma, secretory cavity, and globose trichome. (E) Transversal section, showing papilas in the abaxial face. (F) Transversal section, showing the trichome globose leaf blade. (G) Transversal section, showing filiform trichomes in the abaxial face of the central vein. $($ Ead $=$ adaxial epidermis $; \mathrm{Eab}=$ abaxial epidermis $; \mathrm{n}=$ venation $; \mathrm{s}=$ stomata $; \mathrm{ts}=$ tetracitic stomata $;$ as $=$ anomocytic stomata; $\mathrm{p}=$ papilla; $\mathrm{t}$ $=$ trichomes; $\mathrm{pp}=$ palisade parenchyma; $\mathrm{pe}=$ spongy parenchyma; and $\mathrm{cs}=$ secretory cavity).

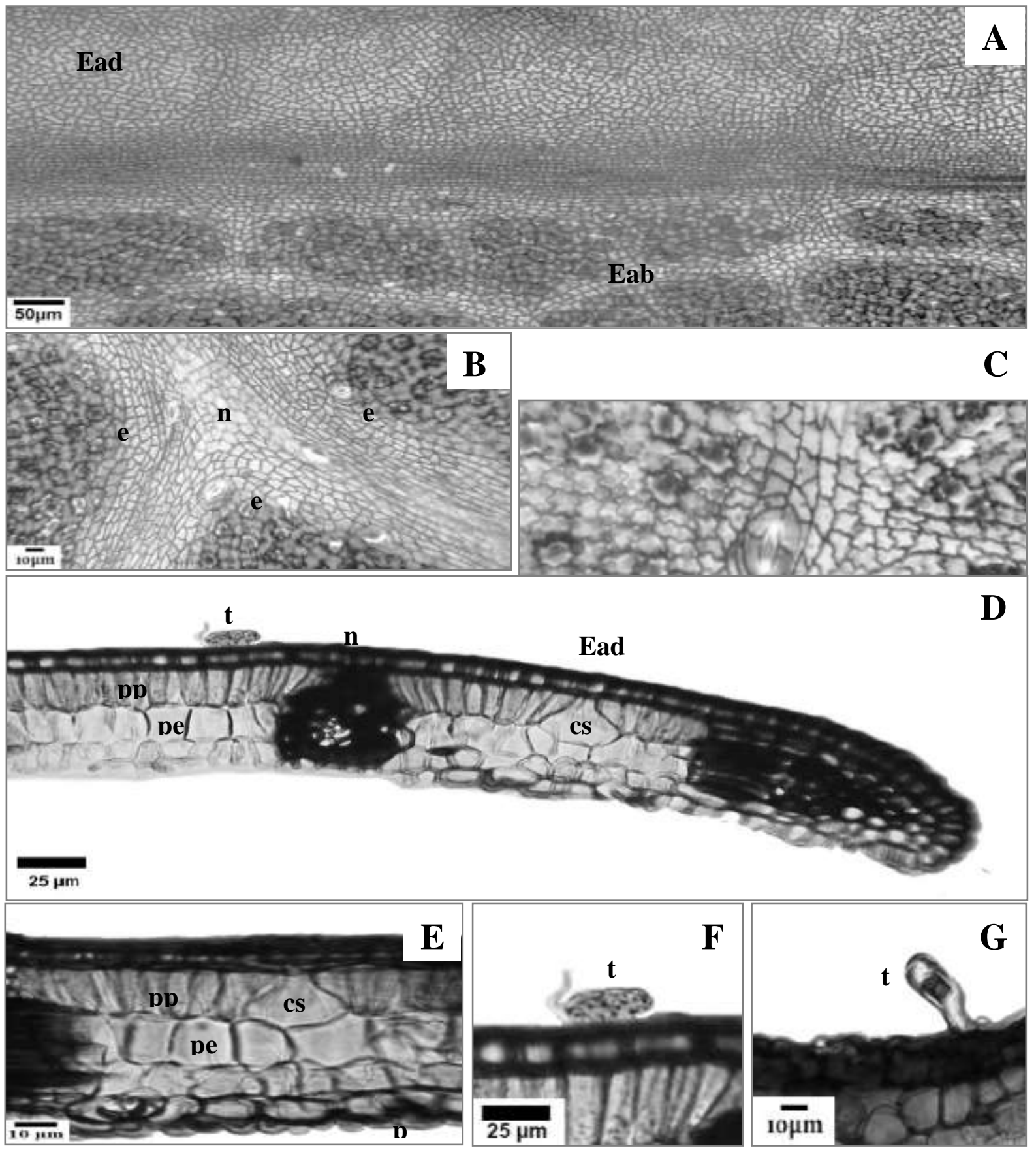

Source: Authors.

The epidermis of V. americana leaves are hypostomatic (Figure 2 - A), with a mean frequency of 719 stomata per $\mathrm{mm}^{2}$. The stomata found are of the anomocytic and tetracitic types, which differ in the occurrence and quantity of subsidiary cells around guard cells, in which the anomocytic stomata has no subsidiary cells, while the tetracitic one has four subsidiary cells. 
Two of them are parallel to guard cells and the other two are not. In V. americana leaves, anomocytic stomata were found scattered throughout the abaxial face and tetracitic stomata on the leaf vein (Figures. 2 - B and C), positioned at the same level as the other epidermal elements (Figure 2 - E).

In the cross-section, the epidermis is uniseriate, consisting of common (ordinary) tabular epidermal cells with a larger periclinal diameter than the anticline (Figure 2 - D).

Globular and filiform glandular trichomes were found on the adaxial leaf blade face and on the abaxial face of the central vein, as displayed in Figure 2-F and 2-G, respectively.

Lusa and Bona (2009), when performing a morphoanatomical analysis of two species belonging to the Caesalpinioideae subfamily, found that in the abaxial face of the epidermis of Bauhinia forficata Link and Bauhinia variegata Linn., there were tectorial and glandular trichomes, distributed over the entire blade, most often over veins.

Secretory structures are present throughout the leaf blade, at the base, mid-region, and apex, occupying the subepidermal region facing the adaxial surface.

Moreira-Coneglian and Oliveira (2006) found that Copaifera langsdorffii and Hymenaea stilbocarpa (Caesalpinioideae) had secretory cavities, not only in the subepidermal region, but also in the middle position, between the two parenchyma constituents of the mesophyll.

In the central vein region, the xylem occupies the central part of the vein, presenting an arc shape. The phloem surrounds the entire xylem and has sclerenchymatic fibers in its periphery. Among these fibers and the abaxial part of the epidermis, approximately five collenchyma strata occur.

In the cross-section of the petiole's median region, it is noted that the central part is composed of an arc-shaped vascular system, similar to that observed in the central vein. There is a parenchyma with a collenchymal aspect in the cortical region of the entire petiole (Figures 2 - A, B, and C), in addition to the starch grains near the vascular system (Figure 2 - D) and secretory cavities scattered throughout the parenchyma (Figure 2 - E).

The occurrence of starch grains and secretory cavities in the petiole region was also described by Silva et al. (2012) in Hymenaea martiana Hayne (Caesalpinioideae - Fabaceae). 
Figure 2 - Transversal section of V. Americana petiole. (A) General aspect of the petiole. (B) Transversal section of the seedling petiole. (C) Transversal section of the stick petiole. (D) Detail of the petiole, showing starch. (E) Detail of the petiole, showing a secretory cavity. $(\mathrm{x}=\mathrm{xylem} ; \mathrm{pl}=$ phloem; $\mathrm{f}=$ fiber; $\mathrm{fp}=$ fundamental parenchyma; $\mathrm{s}=\mathrm{starch} ;$ and $\mathrm{sc}=\mathrm{secretory}$ cavity).
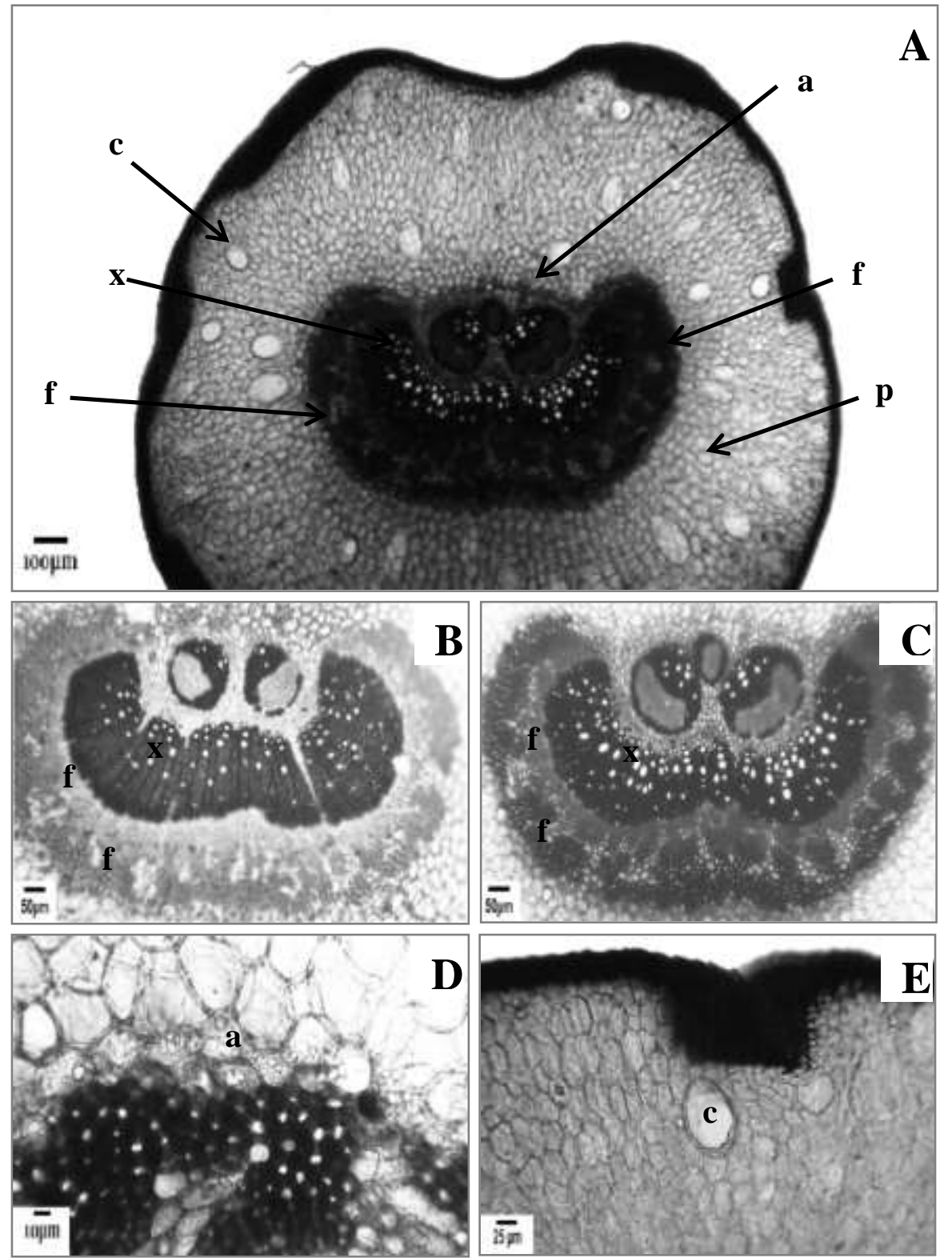

Source: Authors.

During the experimental period, the eco-physiological evaluations showed that the mean relative humidity was $79 \%$, declining to $56 \%$ at the end of the day, during the dry season. In contrast, during the rainy season, humidity was $95 \%$, declining to $72 \%$ at the end of the day. During the experimental period, the leaf humidity was lower than the ambient humidity, following the oscillation of air humidity throughout the day, during both seasonal periods.

Costa and Marenco (2007) observed that leaf moisture declines throughout the day along with a sharp drop in the leaf water potential, reflecting daytime variations in the air temperature and DVP (Table 2). Barbosa et al. (2012) stated that understanding adjustments in the water and carbon exchange of the stomata may be the starting point for understanding the responses of a floristic community to environmental variability 
Table 2 -Values* for the ecophysiological variables of the seedling and stick, stages of V. americana, in different times of the day, during the dry and rainy periods, in Medicilândia county - PA, Brazil.

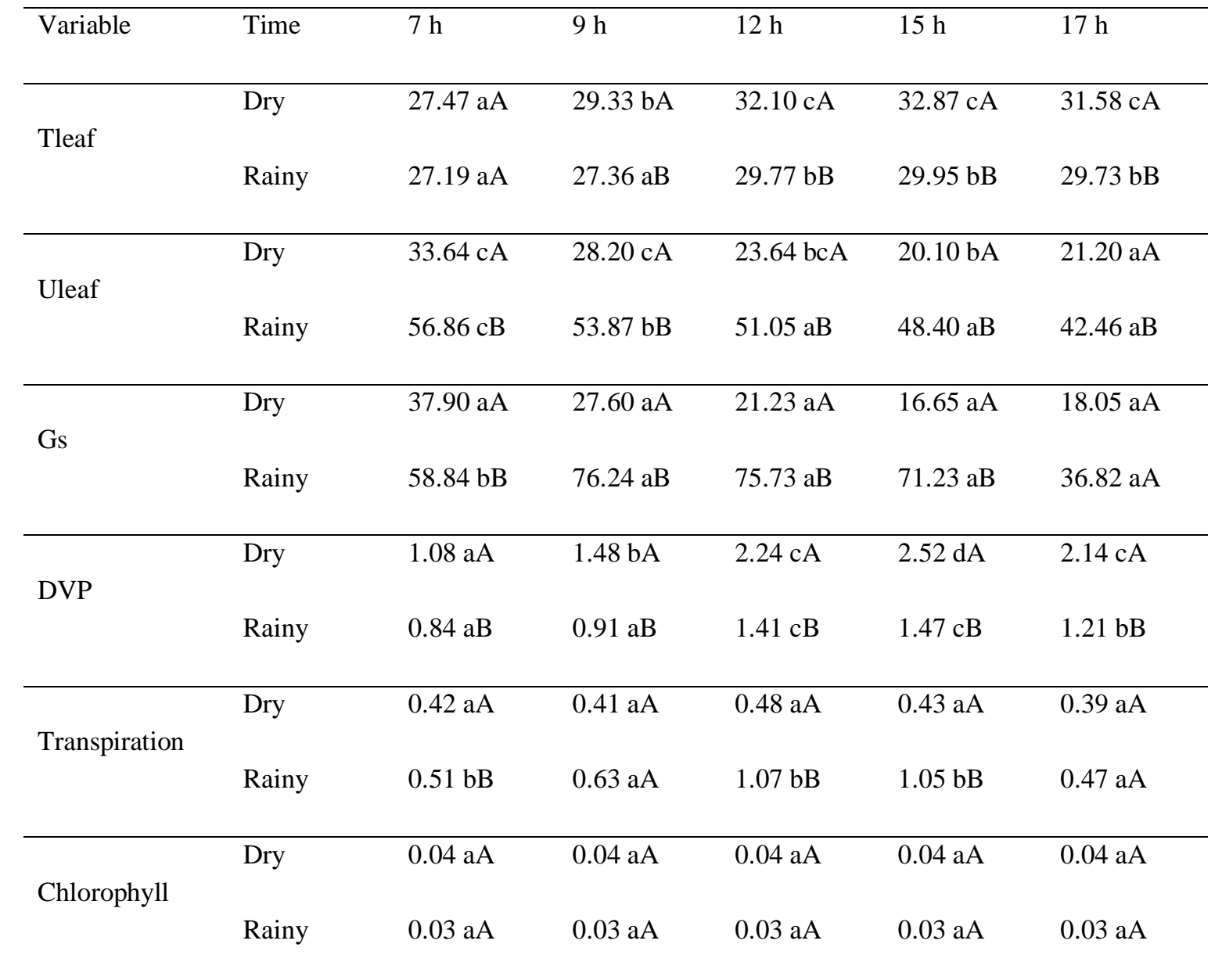

* Mean values followed by the same lower-case letter in the row do not differ significantly, according to the Tukey test at a $5 \%$ probability. Tleaf $=$ temperature of the leaf $\left({ }^{\circ} \mathrm{C}\right)$, Uleaf $=$ moisture of the leaf $(\%)$, Gs $=$ stomatal conductance $(\mu \mathrm{mol} m-2 \mathrm{~s}-1)$, and DVP $=$ deficit of vapor pressure.

Source: Authors.

The plant minimizes the harmful effects of stressful conditions, such as high light intensity, through morphological and anatomical adjustments in the leaves (Costa et al., 2011). In the daytime, the average air temperature was $28.5{ }^{\circ} \mathrm{C}$ during the dry season and $26{ }^{\circ} \mathrm{C}$ during the rainy season, with a mean leaf temperature of $30.7^{\circ} \mathrm{C}$ and $28.8^{\circ} \mathrm{C}$, respectively (Table 2 ).

Unlike the present study, in which the highest values were recorded at $15 \mathrm{~h}$ during the dry period, in a study by Nogueira et al. (2000), the maximum temperatures were observed at $12 \mathrm{~h}$ during both season. The photosynthetically active radiation (PAR) of the forest canopy had a mean of $631 \mu \mathrm{mol} \mathrm{m}-2 \mathrm{~s}-1$ during the dry season and $525 \mu \mathrm{mol} \mathrm{m}-2 \mathrm{~s}-1 \mathrm{during}$ the rainy season.

On the contrary, the PAR that reached the leaves of V. americana plants remained constant during both seasons, with a mean of $35 \mu \mathrm{mol} \mathrm{m}-2 \mathrm{~s}-1$ during the dry season and $26 \mu \mathrm{mol} \mathrm{m}-2 \mathrm{~s}-1$ during the rainy period (Figure 3 ). Of the global solar radiation reaching the canopy, only $5 \%$ has been found to revert to photosynthetically active radiation in $\mathrm{V}$. americana leaves located in the understory forest 
Figure 3 - RDA of the eco-physiological variables (leaf humidity, leaf temperature, stomatal conductance, transpiration, chlorophyll, and deficit of vapor pressure) during the dry and rainy (A), as a function of the seedling and stick stages of V. americana (B), and interactions among the eco-physiological variables: Tleaf, Uleaf, Gs, DPV, T and $\mathrm{Cl}(\mathrm{C})$.
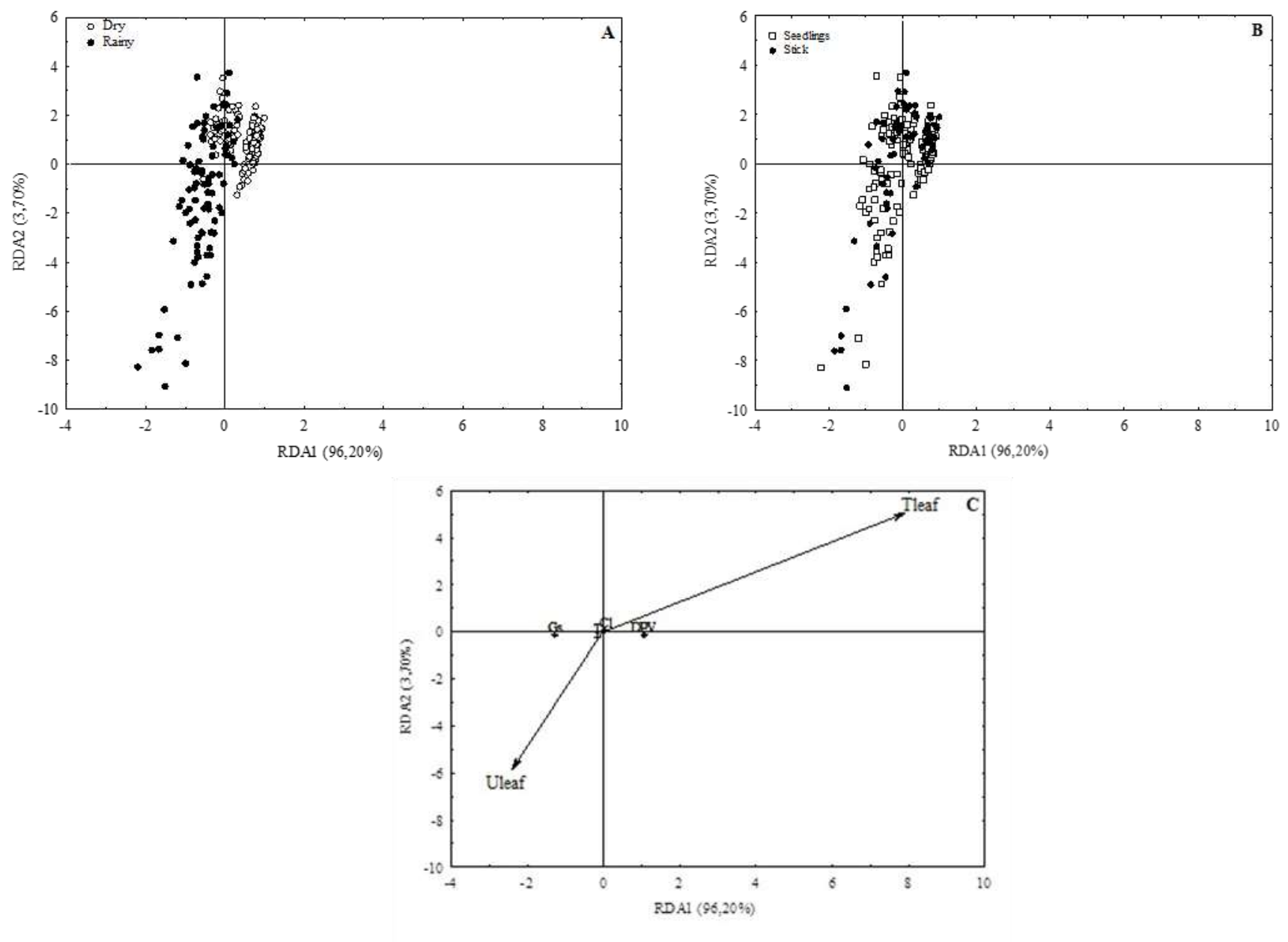

Source: Authors.

This is common in regions with dense vegetation, where the growth and survival of tree species in the understory are limited, especially by the availability of irradiance (Marenco \& Vieira, 2005). Furthermore, Larcher (2006) mentioned that in a natural environment, light is one of the influences that presents the greatest variability, being susceptible to several factors, including cloud passage, sun position, and floristic composition around each analyzed individual.

The eco-physiological variables of V. americana plants directly reflected the oscillations of the environmental aspects, with significant differences between the dry and rainy periods. The leaf temperature and DVP are directly proportional to the room temperature, with a higher air temperature observed during the dry season (a mean of $2.5^{\circ} \mathrm{C}$ higher than that during the rainy season) resulting in higher Tleaf and DVP values, along with lower Uleaf, Gs, and transpiration values. This ecophysiological behavior is the opposite during the rainy season, mainly due to the higher relative air humidity values.

Plants may behave differently between seasons owing to the acclimatization of individuals to the environmental conditions of each period (dry or rainy season). Marenco et al. (2014), when analyzing the physiology of forest species in the Amazon, found that during dry periods, because of increased irradiance and reduced humidity, stomata close as the DVP increases, directly influencing the Gs and water control of forest plants.

In Amazonia, Esquivel-Muelbert, Baker, Dexter et al. (2019) find that greater mortality of wet-affiliated taxa over 
time is related to the degree to which water stress has increased with ineach community, providing direct evidence of the influence of cli-mate on community dynamics.

In relation to the Uleaf and Gs, it was observed that, during the dry season, the two developmental stages had similar behavior, in which the values were decreasing throughout the day. On the contrary, during the rainy season, the mean of the recorded values presented a bigger difference among the developing classes, in which, seedlings showed the lowest values. At $15 \mathrm{~h}$, the seedlings presented a Uleaf of $39 \%$ and Gs of approximately $48 \mu \mathrm{mol} \mathrm{m}-2 \mathrm{~s}-1$, the sticks had a Ufolha of 53\% and a Gs of $92 \mu \mathrm{mol} \mathrm{m}-2 \mathrm{~s}-1$, (Table 2).

In both seasons, the two stages of V. americana development showed higher conductance values in the morning compared with the afternoon. Corroborating with Costa and Marenco (2007), who mention that in the morning when the plant's water potential is higher, higher values of stomatal conductance are usually observed, while in the afternoon, these values are reduced, thus having a very consistent pattern regarding the stomatal conductance variation during the day.

For Sack et al. (2002), the leaf water movement is very important, since stomatal conductance explains between 30 and $80 \%$ of the plant's water flow. Hence, the decrease in the stomatal conductance throughout the day can be attributed to the combined effects of the increased DVP and decreased leaf moisture (Costa \& Marenco, 2007). However, the radiation effect on leaves should not be excluded, a characteristic also observed in the assessment of young plants of Sclerolobium paniculatum Vogel, Fabaceae-Caesalpinioideae in the study conducted by Morais, Rossi, and Higa (2017).

In this study, in the absence of irrigation, Gs values between 18 and $30 \mu \mathrm{mol} \mathrm{m}-2 \mathrm{~s}-1$ were reached. Adaptations to reduce water loss exist during all two growth levels, and the seedling category was expected to underperform but presented the same pattern of plasticity.

During the dry season, plants lost more water, presenting higher DVP values when compared with the loss during the rainy season. In the study by Freitas et al. (2016), when analyzing osmoregulatory compounds in young plants of V. americana submitted to water deficiency, it was verified that Acapu was partially tolerant to water stress. In addition, it was found that V. americana seedlings presented a higher DVP than did sticks, mainly at 12 and $17 \mathrm{~h}$ during both seasons.

The DVP was directly related to the leaf temperature. According to Lima et al. (2016), DVP is a variable that depends upon the humidity and temperature of the air and leaf. The higher the DVP, the greater the amount of water that exits the leaf; so, if this diffusion increases above a rate that cannot be supplied by the plant's vascular structure, the leaf and whole plant can enter into a water stress situation (Streck, 2003).

Regarding the rate of transpiration, it was found that during the rainy season there is distinct behavior among stages of V. Americana development, where sticks have higher values of transpiration, even at the hottest times of the day (Table 2).

The behavior of young plants of V. americana aligns with the research of Moraes (1970), who analyzed the water behavior of an Acapu tree in an Amazon "terra firme" rainforest, where during the rainy season on a partially cloudy day the stomata presented higher transpiration levels at approximately $14 \mathrm{~h}$. In the present study, the peak of transpiration during the rainy season was verified at 12 and $15 \mathrm{~h}$ (Table 2), corresponding to hours of higher air temperatures and radiation, as well as a decrease in the ambient humidity (Table 2).

Considering that transpiration rates and stomatal conductance are correlated with the plant's water transport, which is intensified during the rainy season, it is suggested that sticks showed a higher water use efficiency, which indicates better $\mathrm{CO} 2$ assimilation in this period of the year, according to Marenco (2014). He also claims that carbon dioxide assimilation varies throughout the day to keep up with environmental variations, such as irradiance and water availability.

Although a role for stomatal opening seems apparent across all land plants, the role and process of stomatal closure seems much less uniform, particularly if basal plants are considered. In vascular plants, however, a primary stomatal function is the action to close the pore during water stress to reduce transpiration and maintain plant hydration thus avoiding damage to 
the plant vascular system (Brodribb \& McAdam, 2017)

In the seedlings, although the leaves were already fully expanded, they were still at the beginning of maturity, a factor that contributed towards the constant chlorophyll content between seasons. While in the sticks, chlorophyll presented high values during the dry period and lower values during the rainy season.

The highest values recorded during the dry season (November 2015) and the lowest values during the rainy season (April 2016) can be attributed to the temporal effect, as the chlorophyll rate tends to decrease with the leaf maturation process. For Marenco and Lopes (2009), the low photosynthesis rates in senescent leaves are related mainly to chlorophyll degradation and loss of chloroplast functionality.

Certainly, the variation in the eco-physiological behavior of acapu is strongly related to environmental aspects, where the first two axes of the RDA explained $99.90 \%$ of this variation, with the first explaining $96.20 \%$ and the second $3.70 \%$.

It was observed that each stage of $\mathrm{V}$. Americana development behaved in a certain way to environmental variations. Sticks showed more favorable responses to the variations in the air temperature and humidity, showing high Gs rates and lower DVP values, taking advantage of the available resources during the rainy season (Figure 3).

The leaf temperature and PAR are positively correlated with the DVP, and negatively correlated with the leaf moisture content, which is positively correlated with the stomatal conductance of V. americana plants (Figure 3 - C).

In a study by Costa and Marenco (2007), by analyzing the effects of climate variation on the eco-physiological variables of Andiroba (Carapa guianensis Aubl.), it was possible to observe a positive correlation between the leaf temperature and DVP, where the variation in the leaf temperature closely reflected the changes in the DVP. V. americana presented a negative correlation between the DVP and stomatal conductance. Thus, the higher the DVP, the lower the conductance, following the common pattern of forest species (David et al., 2002).

Rodrigues et al. (2011) investigated the variations of stomatal conductance in the rainy and dry seasons and its dependence relations with meteorological variables measured in an Amazonian mangrove ecosystem. Stomatal conductance followed the tendency of the radiation balance variation, reaching maximum values during the day and minimum values at night. The conductance showed greater fluctuations in the rainy season, with mean value of gs $=0.015 \mathrm{~m} \mathrm{~s}^{-1}$, however smaller in magnitude than in the dry season. During the dry season, the mean value was gs $=0.027 \mathrm{~m} \mathrm{~s}^{1}$.

Seasonality was observed to influence the ecophysiology of E. simonis, with a greater influence of rainfall and soil moisture on stomatal conductance. Stomatal conductance (gs) also exhibited significant differences among months, with lowest values in the dry season, varying from $0.02 \mathrm{~mol} \mathrm{~m}-2 \mathrm{~s}-1$ (September) to $0.127 \mathrm{~mol} \mathrm{~m}-2 \mathrm{~s}-1$ (May). On the other hand, with water stress during the dry season the species exhibited distinct physiological responses, with lower photosynthetic rates due to the closure of stomata as a physiological strategy to avoid excessive water loss (Ribeiro et al., 2018).

In dry conditions transpiration by large trees may be maintained from stored water for up to a week, but flows from storage may be more important in refilling cavitated xylem elements and hence ensuring that the overall hydraulic conductivity of stems is not reduced. Hydraulic redistribution of water in the soil may make a contribution to facilitating root growth in dry soils and modifying resource availability.

Consequently, even though different eco-physiological responses of seedlings and sticks, were shown, the growth increment of V. americana plants did not show significant differences among the developmental classes. This is in agreement with Magalhães et al. (2014), when analyzing the factors that affected the growth and photosynthesis of seedlings in the Amazon, who found that contrary to what has been observed in adult trees, for trees in the juvenile phase there is no effect of seasonality on their growth and development. 


\section{Conclusion}

The most striking anatomical characteristics of the young leaves of V. americana plants were: the presence of a layer of palisade parenchyma on the abaxial surface, with cells flatter than those present in the adaxial palisade parenchyma layer; presence of trichomes; a large amount of papillae on the abaxial face; subepidermal secretory structures; and giant tetracitic stomata in the vein.

The variation in the local climate, temperature, and air humidity under natural conditions were the main factors responsible for the eco-physiological behavior of V. americana. During the dry season, the plants presented a high leaf temperature, high DVP, low transpiration rate, and low stomatal conductance. During the rainy season, the leaf moisture and stomatal conductance were higher.

\section{Acknowledgments}

To the Amazon Foundation for the Support of Studies and Research - FAPESPA, through the financial resource, via Edital 05/2014, of the research project "Selection of matrices of Vouacapoua americana (acapu) as a community management instrument for forest management in the PDS Virola-Jatobá, Anapu-PA"

\section{References}

Allen, C. D., Macalady, A. K, Chenchouni, H., Bachelet, D., Mcdowell, N., Vennetier, M., Kitzberger, T., Rigling, A., Breshears, D. D., Hogg, E. H., Gonzalez, P., Fensham, R., Zhang, Z., Castro, J., Demidova, N., Lim, J-H., Allard, G., Running, S. W., \& Cobb, M. (2010). A global overview of dry and heat-induced tree mortality reveals emerging climate change risks for forests. Forest Ecology and Management, 259 (4), 660-84. ".

Another wrong example: "Barbosa, J. P. R. A. D., Rambal, S., Soares, A. M., Mouillot, F., Nogueira, J. M. P., Martins, G. A. Plant physiological ecology and the global changes. (2012). Ciência e Agrotecnologia, 36(3), 253-269. https://dx.doi.org/10.1590/S1413-70542012000300001

Barbosa, J. P. R. A. D., Rambal, S., Soares, A. M., Mouillot, F., Nogueira, J. M. P. \& Martins, G. A. (2012). Plant physiological ecology and the global changes. Ciência e Agrotecnologia, 36(3), 253-69. https://dx.doi.org/10.1590/S1413-70542012000300001

Batista, L. A., Guimarães, R. J., Pereira, F. J., Carvalho, G. R., \& Castro, E. M. Anatomia foliar e potencial hídrico na tolerância de cultivares de café ao estresse hídrico. (2010). Revista Ciência Agronômica, 41 (3): 475-481. https://dx.doi.org/10.1590/S1806-66902010000300022 (Cons. 31/10/2017).

Berry, J., \& Bjor, K. O. Photosynthetic response and adaptation to temperature in higher plants. (1980). Annual Review of Plant Physiology, 31: 491-543. https://www.annualreviews.org/doi/pdf/10.1146/annurev.pp.31.060180.002423

Boeger, M. R. T., \& Wisniewski, C. Comparação da morfologia foliar de espécies arbóreas de três estádios sucessionais distintos de floresta ombrófila densa (Floresta Atlântica) no Sul do Brasil. (2003). Revista Brasileira de Botânica, 26 (1): 61-72.https://dx.doi.org/10.1590/S0100-84042003000100007

Brodribb, T. J., \& Mcadam, S. A. M. Evolution of the Stomatal Regulation of Plant Water Content. (2017). Plant Physiology, 174 (2) 639-649; $10.1104 /$ pp. 17.00078

Buck, A. L. New equations for computing vapor pressure and enhancement factor. (1981). Journal of Applied Meteorology, 20: 1527-1532. https://doi.org/10.1175/1520-0450(1981)020<1527:NEFCVP>2.0.CO;2.

Christopherson, R. W. Geossistemas - Uma introdução à geografia física. (2012): Bookman, (7a ed.). https://www.researchgate.ne t/publication/320911111_Geossistemas_uma_introducao_a_Geografia_Fisica_9_Ed_Portugues_Robert_W_Christopherson_Ginger_HBirkeland_Traducao_e_ Revisao_Tecnica

Costa, G. F., \& Marenco, R. A. (2007). Fotossíntese, condutância estomática e potencial hídrico foliar em árvores jovens de andiroba (Carapaguianensis). Acta Amazonica, 37 (2): 229-234. https://dx.doi.org/10.1590/S0044-59672007000200008.

Costa, V., Almeida, G., Chagas, M., \& Pimentel, R. Indicadores Anatômicos Foliares Como Estratégias de Defesa Contra Elevada Incidência Luminosa (Anatomical Leaves Indicators as Defense Strategies Against High Luminosity). (2012). Revista Brasileira de Geografia Física, 4(2), 349-364. https://doi.org/10.26848/rbgf.v4.2.p349-364.

David, T. S., Ferreira, I., Pereira, J. S., Cohen, S., David, J. S. Transpiração em árvores isoladas de um montado de azinho: evolução sazonal e condicionantes

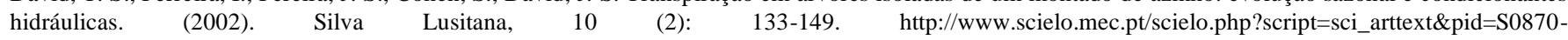
$63522002000200001 \& \operatorname{lng}=$ pt\&tlng=pt.

Esquivel-Muelbert, A., Baker, T. R., Dexter, K. G., et al. Compositional response of Amazon forests to climate change. (2019). Global Change Biology 25: 39- 56. https://doi.org/10.1111/gcb.14413

Fermino Júnior, P. C. P. (2004) Anatomia ecológica comparada de folhas de Guapiraopposita (Vell.) Reitz (Nyctaginaceae) na vegetação de restinga e na Floresta Ombrófila Densa, Dissertação, Universidade Federal de Santa Catarina. http://repositorio.ufsc.br/xmlui/handle/123456789/87303 
Fisch, G., Marengo, J. A., \& Nobre, C. A. (1998). Uma revisão geral sobre o clima da Amazônia. Acta Amazônica, 28 (2): 101-126. http://www.scielo.br/pdf/aa/v28n2/1809-4392-aa-28-2-0101.pdf

Freitas, J. M. N., Costa, R. C. L. da, Oliveira Neto, C. F. de, Silva, D. A. S., Conceição, S. S., Okumura, R. S., Viégas, I. J. M., Cardoso, K. P. S., Siqueira, J. A. M., Souza, L. C. de, \& Nascimento, V. R. do. (2016). Osmoregulators compounds in young plants of Vouacapoua americana Aubl. submitted to water deficit. International Journal of Current Research, 8 (10): 40343-40349. http://www.journalcra.com/sites/default/files/issue-pdf/18066.pdf

Gerlach, G. (1969). Botanische Mikrotechnik. Stuttgard: Georg ThiemeVerlag 344 p.

Gurevitchet, J., Scheiner, S. M., \& Fox, G. A. (2009). Ecologia Vegetal, Artmed, , 574 p.

Hoffmann, E., Dallacort, R., Carvalho, M., Yamashita, O., \& Barbieri, J. (2018). Variabilidade das chuvas no Sudeste da Amazônia paraense, Brasil (Rainfall variability in southeastern Amazonia, Paraense, Brazil). Revista Brasileira de Geografia Física, 11(4), 1251-1263. https://doi.org/10.26848/rbgf.v11.4.p12511263.

Johansen, D. A. (1940). Plant microtechnique, McGraw-Hill Book Company Inc. 523 pp.

Kaiser, E. (1880). VerfahrenzurHerstellungeinertadellosen Glycerin-Gelatine. Botanisches Zentralbl, 180: 25-26.

Landsberg, J. J. (1986). Physiological ecology of forest production: Academic Press, 198 p.

Larcher, W. (2006). Ecofisiologia vegetal: RiMa, (3a ed.) 550 p.

Landsberg, J., Waring, R., \& Ryan, M. (2017). Water relations in tree physiology: where to from here? Tree Physiology, 31;37(1):18-32. 10.1093/treephys/tpw102.

Lima, M. J. A., Farias, V. D. S., Costa, D. L. P., Sampaio, L. S., \& Souza, P. J. P. O. Efeito combinado das variáveis meteorológicas sobre a condutância estomática do feijão-caupi. (2016). Horticultura Brasileira, 34 (4), 547-553. https://dx.doi.org/10.1590/s0102-053620160414

Lusa, M. G., \& Bona, C. Análise morfoanatômica comparativa da folha de Bauhinia forficata Link e B. variegata Linn. (Leguminosae, Caesalpinioideae). (2009). Acta Botanica Brasilica, 23 (1): 196-211. https://dx.doi.org/10.1590/S0102-33062009000100022

Magalhães, N. S., Marenco, R. A., \& Camargo, M. A. B. Do soil fertilization and forest canopy foliage affect the growth and photosynthesis of Amazonian saplings? (2014). Scientia Agricola, 71: 58-65. https://dx.doi.org/10.1590/S0103-90162014000100008

Marenco, R. A., Antezana-Vera, S. A., Gouvêa, P. R. dos S, Camargo, M. A. B., Oliveira, M. F. de, \& Santos, J. K. DA S. Fisiologia de espécies florestais da Amazônia: fotossíntese, respiração e relações hídricas. (2014). Revista Ceres, 61(Suppl.): 786-799. https://dx.doi.org/10.1590/0034-737x201461000004

Marenco, R. A., \& Lopes, N. F. (2009). Fisiologia Vegetal: Fotossíntese, respiração, relações hídricas, nutrição mineral, (2a ed.): Editora UFV, 451p.

Marenco, R. A., \& Vieira, G. Specific leaf area and photosynthetic parameters of tree species in the forest understory as a function of the microsite light environment in Central Amazonia. (2005). Journal of Tropical Forest Science, 17: 265-278. www.jstor.org/stable/23616574

Marques, R., Freire, C., Nascimento, H., \& Nogueira, R. Relações Hídricas e Produção de Pigmentos Fostossinteticos em Mudas de Eugenia Uniflora 1. Sob Condições de Salinidade (Water Relations and Production of Pigments in Seedlings Photosynthetic Eugenia Uniflora 1. Under Salinity Conditions). (2011). Revista Brasileira de Geografia Física, 4(3), 497-509. https://doi.org/10.26848/rbgf.v4.3.p497-509

Mccree, K. J. Photosyntetically active radiation. In: Lange, O. L., Nobel, P. S., Osmond, C. B., Ziegler, H. (eds.).( 1981). Encyclopedia of Plant Physiology, 12 (A): 41-55.

Ministério do Meio Ambiente - MMA. ( 2014). Portaria n. 443, de 17 de dezembro de 2014. Ministério do Meio Ambiente, Brasil. Diário Oficial da União, seção 1, Edição nº 245 de 18/12/2014, pp. 110-121.

Moraes, V. H. F. (1970). Comportamento hídrico de Vouacapoua americana Aubl. (acapu) e Licania macrophylla Benth (anoerá), nas condições de mata Amazônica de terra firme. Série: Botânica e Fisiologia Vegetal, 1 (1): 7-21. https://www.infoteca.cnptia.em brapa.br/infoteca/bitstream/doc/376101/1/BOTANICAFISIOLOGIAVEGETAL.pdf

Moreira-Coneglian, I. R., \& Oliveira, D. M. T. Anatomia comparada dos limbos cotiledonares e eofilares de dez espécies de Caesalpinioideae (Fabaceae). (2006). Revista Brasileira de Botânica, 29 (2): 193-207.

Morais, R. R. DE, Rossi, L. M. B., \& Higa, R. C. V. Trocas gasosas de plantas jovens de taxi-branco submetidas à variação de temperatura foliar e suspensão da irrigação. (2017) Ciência Florestal, 27 (1): 97-104. https://dx.doi.org/10.5902/1980509826450

Nogueira, R. J. M. C., Moraes, J. A. P. V., \& Burity, H. A. Curso diário e sazonal das trocas gasosas e do potencial hídrico foliar em aceroleiras. (2000). Pesquisa Agropecuária Brasileira, 35 (7): 1331-1342.

Oksanen, J., Blanchet, F. G., Kindt, R., Legendre, P., Minchin, P. R., O'hara, R. B., Simpson, G. L., Solymos, P., Stevens, M. W. H., \& Wagner, H. (2015). Vegan: Community Ecology Package. R package version 2.3-0.2015, http://CRAN.R-project.org/package=vegan (Cons 27/10/2017).

R Development Core TEAM. (2015). R: A language and environment for statistical computing. R Foundation for Statistical Computing, Vienna, Austria. http://www.R-project.org/ (Cons 27/10/2017)

Ribeiro, J. E. S., Barbosa, A. J. S., Lopes, S. de F., Pereira, W. E., \& Albuquerque, M. B. de. Seasonal variation in gas exchange by plants of Erythroxylum simonis Plowman. (2018). Acta Botanica Brasilica, 32(2), 287-296. Epub February 15, 2018. https://dx.doi.org/10.1590/0102-33062017abb0240 
Research, Society and Development, v. 10, n. 3, e4510312960, 2021

(CC BY 4.0) | ISSN 2525-3409 | DOI: http://dx.doi.org/10.33448/rsd-v10i3.12960

Rodrigues, H. J. B., Costa, R. F., Ribeiro, J. B. M., Souza Filho, J. D. C., Ruivo, M. L. P., \& Silva Júnior, J. A. Variabilidade sazonal da condutância estomática em um ecossistema de manguezal amazônico e suas relações com variáveis meteorológicas. (2011). Revista Brasileira de Meteorologia, 26 (2): 189-196. https://dx.doi.org/10.1590/S0102-77862011000200003 (Cons. 27/10/2017).

Sack, L., Melcher, P. J., Zwieniecki, M. A., \& Holbrook, N. M. The hydraulic conductance of the angiosperm leaf lamina: a comparison of three measurement methods. (2002). Journal of experimental botany, 53 (378): 2177-2184.

Silva, J. M. N., Lopes, J. C. A., Oliveira, L. C., Silva, M. A., Carvalho, J. O. P., Costa, D. H. M., Melo, M. M. S., \& Tavares, M. J. M. (2005). Diretrizes para instalação e medição de parcelas permanentes em florestas naturais da Amazônia Brasileira: Embrapa Amazônia Oriental, 68 pp.

Silva, M. S., Leite, K. R. B., \& Saba, M. D. Anatomia dos órgãos vegetativos de Hymenaea martiana Hayne (Caesalpinioideae-Fabaceae):espécie de uso medicinal em Caetité-BA. (2012). Revista Brasileira de Plantas Medicinais, 14 (4): 673-679. https://dx.doi.org/10.1590/S1516-05722012000400015

Streck, N. A. (2003). Stomatal response to water vapor pressure deficit: an unsolved issue. Revista Brasileira Agrociência, 9 (4): $317-322$.

Tomlinson, P. B. (1990). The strutuctural biology of palms, Clarendon Press, Oxford. 465p.

Passos, M. A. B., \& Mendonça, M. S. Epiderme dos segmentos foliares de Mauritia flexuosa L. f. (Arecaceae) em três fases de desenvolvimento. (2006). Acta Amazonica, 36 (4): 431-436. https://dx.doi.org/10.1590/S0044-59672006000400005

Pivovaroff, A. L., \& Cook, V. M. W., Santiago, L.S. Stomatal behaviour and stem xylem traits are coordinated for woody plant species under exceptional drought conditions. (2018). Plant Cell Environ. Nov; 41(11):2617-2626. doi: 10.1111/pce.13367. Epub 2018 Aug 7.

Wang, W. X., Vinocur, B., Shoseyov, O., \& Altman, A. Biotechnology of plant osmotic stress tolerance: physiological and molecular considerations. (2001). Acta Horticulturae, 560: 285-292.

Watson, L. (1981). An automated system of generic description for Caesalpinioideae, and its application to classification and key-making. IN Pohill RM, Raven PH (eds.) Advances in Legume Systematics part 1. Kew: Royal BotanicalGardens, pp. 65-80.

Werner, C., Ryel, R. J., Correia, O., \& Beyschlag, W. Structural and functional variability within the canopy and its relevance for carbon gain and stress avoidance. (2001). Acta Oecologica, 22 (2): 129-13 